\title{
Productivity, New Paradigm for Management, Accountant and Business Environment
}

\author{
Reza Daghani (Corresponding author) \\ Management and Economics Faculty, Tarbiat Modares University \\ Tehran, Iran \\ E-mail: r.daghani@modarec.ac.ir
}

Mohammadali Nasr

Economics and Accounting Faculty, Islamic Azad University, Tehran Central Branch

Shiraz, Iran

E-mail: Mohammadalinasr@gmail.com

Mostafa Ahmad Khanbeigi

Management Faculty, University of Tehran

Tehran, Iran

E-mail: M.a.khanbeigi@ut.ac.ir

Received: November 23, $2010 \quad$ Accepted: January 4, $2011 \quad$ doi:10.5539/ijbm.v6n6p247

\begin{abstract}
Many of management accounting experts and productivity assessor organizations, including Asian productivity organization, European Union and American productivity center, believe that productivity measurement is one of the primary objectives in evaluating company activities for long term period. Therefore, management team is always requested to provide decision makers with reports about the way of implementing strategic plans of company and their results. In this way, they will be able to evaluate company's performance by comparing it with successive periods and also with other similar companies. Hence, discussions related to productivity measurement and its methods, e.g. Total Factor Productivity (TFP) and Total factor productivity Growth (TFPG) can help decision makers in this evaluation. Most research about productivity are performed by Economist, industrial engineers and production specialists but managerial accountants don't pay attention to it; Accounting textbooks virtually ignore issues of productivity measurement, and journals contain few articles on this subject, probably "there isn't a comprehensive criteria for productivity measurement". In this article, by focusing on management accounting, different aspects of productivity have been explained and more than 32 studies and researches for period 1991to2010 have been reviewed. In addition, the significance of Studies related to the productivity measurement in the world has been discussed.
\end{abstract}

Keywords: Productivity, Quality, Management accounting, Paradigm

\section{Introduction}

Recent years have witnessed far-reaching changes in nature and organization of industrial production and significant development in finding common needs of management, in particular, issues relating to make a decision in various situations and presenting them in a quantitative framework in order to be used in any time and situation (Etemadi, 2001). Organizations have some common features in spite of their disagreement about managerial issues such as decision making issues and governing organizations. Specially, these organizations have mutual interaction with each other in different social, political and economical environments and it is not possible to consider one organization independent of others even if it has a very special condition.

It seems that a manager cannot understand the effects of his decisions without doing evaluation. Furthermore, 
evaluation doesn't merely provide numbers. Rather, manager uses their concepts as a criterion for his future decision making.

One of the issues related to evaluation, which has attracted the attentions of so many managers and analyzers in recent decades, is "productivity" in a way that it has turned to be a new paradigm in the modern business world. Neo-classicists believe that companies have to operate with full production capacity. Although the experience of production units has revealed that this is impossible, it is the certain economic fact for economists and is used for decision making in theoretical economy era.

One of the related issues of productivity is the efficiency of production. Preliminary view of developing different methods for studying efficiency can be found in a seminar held in the United States in 1957. In that seminar M.G.Farral presented "production-efficiency evaluation" and introduced non-parametric methods of measuring as sources for evaluating efficiency of productions. He also determined the inefficiency by using efficient production frontier. Today, most businesses focus on the attainment and maintenance of a desirable level of profit. But authors believe that it is also important to understand the drivers which lead to changes in profit. After presentation of Farral, some definitions and calculations were stated by different sections of management. For example, Ramsey stated: "Productivity is the optimized utilization and management of all available resources, investigation into the best known resources, the generation of new resources, through creative thinking, innovation technology, and research and development. It combines the best use of all areas of knowledge, improvement techniques, methods, and approaches for the production and distribution of quality goods and services at minimum unit cost in an ethical and legal manner with due regard for the total environment" (Ramsey, 2006) .The empirical application of these techniques to estimate efficiency and/or productivity has resulted in a multitude of studies in numerous areas for instance agriculture, utilities, education, health economics, transportation, labour economics, management science, environmental economics, and financial institutions (Campbell et al, 2002).

This paper is organized in four sections. In first section, first of all, the productivity and quality, and productivity and variances have been compared. Then, Productivity paradigm in business, the way of measuring productivity and two methods of productivity measurement (indexes and Ratios) have been reviewed. The second section designated to Key innovations in productivity, namely, the relationship between R\&D and productivity, customer oriented perspectives, supply chain management. In the third section, productivity studies in the world will be introduced. Conclusion is presented in the fourth section.

\section{Productivity: misconceptions, paradigm and measurement}

Before reviewing different aspects of productivity, it would be useful to discuss about some misconceptions about productivity. Sometimes productivity and quality, and in the other cases the changes caused by productivity and those caused by foreseen factors in previous periods (variances), are used interchangeably. But there are some differences between productivity-quality and productivity - variances that will be explained in remaining parts of paper.

\subsection{Productivity and Quality}

Generally, productivity and quality concepts are used instead of each other. But there are some differences between these two concepts. In this part, in order to clear these differences, three deferent viewpoints (organization, managements, and customers) have been reviewed.

There are opposite views about Productivity and quality, because Productivity is just an inside view and quality covers both outside and inside view in organizations. Management understands the term productivity, but quality is more easily understood by the workforce and customers. It is not possible to achieve one without the other. Most of the business excellence frameworks have their roots in productivity, but the output is quality (Blocher et al, 2008). Quality needs to be more strictly defined. In a project, the primary usage of Cost of Quality (CoQ) reporting is to provide project management with a tool for evaluating trends in the CoQ. By reviewing the CoQ analysis over time, the project team can identify possible areas for change or improvement, and implement corrective action to address CoQ increases (Grason, 1987).

The cost associated with quality are divided into five categories, Prevention, Appraisal, Internal and External defect and hidden Costs .we recognize quality when we use or hear about product of company and so, we recognize poor quality when it is absent such as using of the term quality to emphasize both the technological and value dimensions of an innovation (Lanjouw and Schankermann, 2002). In the customer-driven excellence model, "Performance and quality are judged by an organization's customers." (1) compares the productivity and the quality from the organization, customers and management's point of view. 
Reviewing various business excellence frameworks from people's perspectives, without constant engagement of the workforce and stakeholders in an enterprise, a drive for achieving profitability cannot have expected results. The two key drivers in successful organizations, according to the business excellence frameworks and the most leading top management educators, are the leadership and the customer. We can employ customer voice and critical to quality (CTQ) analysis in order to extract Customers expatiations, requests and ideas. Organization will review these opinions and ideas then convey them to operational managers for appropriate feedback and provide customer's needs. One of the main factors which should be considered is quality. As we have already discussed quality and productivity are two sides of the coin which need to be considered simultaneously. We would say that satisfying customer's needs and productivity are intertwined. Figure (1), shows this relation between Productivity and Quality with signing their direct communication.

\subsection{Productivity and Variances}

In addition to the discussion of productivity and quality, sometimes, especially in the case of productivity improvement analysis, productivity and variances are used mistakably. Actually, variances are the difference between the things that have happened and the things that must be happened. So it is necessary to distinguish between productivity and variances.

There are some differences between these two concepts that expressed as follow:

1) Principally, those managers who desire to show annual improvement in operations compare usage variances from year to year. But this would not be meaningful if standards change from one year to the next, or if significant annual fluctuations in output occur. Usage variances are typically not computed as ratios and hence are not normalized for actual levels of output. Basically, variance analysis provides only a static, one-period retrospective analysis of performance. Although we will show, in the next section of this paper, how to make variance analysis more dynamic in practice. We did not observe any organization which adopts a multi period perspective without using a summary measure of productivity. That is, when operating managers describe their improved performance, they tend to say, "Our productivity has been increasing." Rather than saying, "Our usage variances improved or unfavorable variances change to favorable."Although the latter statement means that operating performance has improved but it should be noted that it does not help us understand the significance of the cost improvement (Banker et al, 1987).

2) Productivity measurement systems analyze performance based on actual outputs and inputs in different time periods. The productivity measurement system can be viewed as a variance analysis of the actual costs incurred in successive periods.

3) Variance analysis only is a period analysis perspective and does not reflect manager's point of view with regard to performance improvement. Managers hope to see performance improvement which cannot be measured by variance analysis. Otherwise, productivity change is a long-term valuation perspective, which is caused by continuous improvement of operations, in this perspective we also pay attention to both goals and events occurred over business operation (Horngren, et al, 2006).

4) Productivity measurement systems analyze performance based on actual outputs and inputs in different time periods. The productivity measurement systems can be viewed as a variance analysis of the actual costs incurred in successive periods. In contrast, traditional management accounting systems used to analyze the performance within a given period by comparing the actual quantities and prices with predetermined standards for quantities and prices.

5) Variance analysis is also a week alternative for productivity measurement; because if evaluation standards be unrealistic or obsolete, evaluation will be effected and cannot show performance of period. In this unfortunately not uncommon situation, variances become difficult to interpret within a period, much less period to period. But productivity evaluation is a realistic evaluation system because it pays attention to the real performance and comparing it with successful performances of last period. It is noteworthy to say that even with a reasonably well-functioning standard cost system the method of assigning overhead to products can lead to mysterious variances. These variances arise from using cost centers and burden rates that are too aggregate. In this way, when products pass through the cost centers, the method can not reflect the actual consumption or overhead resources (Banker et al, 1987).

6) One of the advantages of productivity measurement systems over the traditional variance analyses is the focus upon the period-to-period changes in productivity. In contrast, the variance analysis of standard cost systems focuses on comparisons within a given year. The variances in one accounting period are 
normalized and aggregated so that they can be compared conveniently to the variances reported in subsequent periods (Horngren et al 2006).

Taking the above cases into account, considering the variances regardless of the motives of productivity measurement will fail the performance assessment. If the entire standard cost system doesn't reflect the current operation environment appropriately, it cannot be a reliable source for evaluation. Unlike the traditional variance analyses, productivity measurement, which establishes a comparison between the actual period and expectations, present a criterion which can be relied upon for future courses. But productivity measurement faces with problems. Existence of several output items which are produced continuously (jointly) or mass (cumulative) inputs, which are not separable and related to specific product, are some of problems that this measurement system faced with them.

After explaining productivity and understanding its relationship with quality and variances, the other topic that should be explained is productivity measurement. In this way, productivity paradigm has been considered then productivity measurement and its improvements and challenges have been reviewed.

\subsection{Productivity Paradigm}

Classifying, evaluating, recording and reporting financial events are the main duties of accounting and final approved management and since changes in productivity evaluation views have affected financial events of business enterprises, therefore they have affected recognizing and measuring those events, it is necessary to be familiar with productivity evaluation methods and their reflection in financial reports. In addition, accounting management cannot fulfill his duties unless adopt itself with new changes. In this way, studying accounting paradigms help us to understand productivity evaluation and measurement changes in business level. Therefore, in this section, process of changing accounting thoughts in relation to the productivity evaluation and measurement has been reviewed.

The Statement on Accounting Theory and Theory Acceptance (1977) recognizes three approaches that had been proposed to build accounting theory: the classical (true -income /inductive), the decision usefulness and The Information-Economics approaches (Note 1).

All of these approaches paid attention to the productivity but in different aspects.

The classic view focuses on studying and improving accounting performance. In this way, defined goals will be achieved.

In the decision usefulness view, potential of productivity, as a criterion, and its relation with facilitating decision making and its usages have been reviewed. In other words, in this view, predictability of the measurements methods has been examined based on their powers in predicting economics events and their effects on performance. Productivity measurement has special attention to this aspect.

Finally, in The Information - Economics method, defining value of a variable in information system from decision makers' perspective has a crucial importance. In this framework, the main focus is on elements that are necessary for measuring expected productivity in a special information system.

\subsection{Measuring the level of the productivity}

During last centuries, productivity measurement has faced with substantial changes. Specially, by introducing new procedures, like index approach, ratio approach and Farral efficiency frontier, new views for evaluating efficiency, effectiveness, and finally, productivity of business enterprise have been discussed. These views highlight espial attention to the productivity concepts.

As stated in previous sentence, there are many Models and methods of measuring the level of the productivity which are offered by economists, engineers, project managers and mathematicians, namely: Index approach, production function, utility approach, financial ratio approach, unit cost approach and mathematical models. Index number methods are mainstay of estimating national productivity.

\subsubsection{Index approach}

Index number methods are the mainstay methodology for estimating national productivity. Different conceptual meanings have been proposed for a TFPG (Note 2) index. The alternative concepts are easiest to understand for the case in which the index number problem is absent: a production process with one input and one output (a 1-1 process).Diewert and Nakamura show that four common concepts of TFPG, namely, The growth rate for the rate of transformation of total input into total output, The ratio of the output and the input growth rates, The rate of growth in the real revenue/cost ratio, The rate of growth in the margin after controlling for price change, all lead to the same measure in this 1-1 case(Note 3) However, with only one input and one output it is not possible 
to introduce aggregation issues. To do that, they move on to a production process with two inputs (a 2-1 process). After that they present several of the commonly used index number formulas for a general $\mathrm{N}$ input, $\mathrm{M}$ output production scenario. One result demonstrated is that a Paasche, Laspeyres or Fisher index number formula provides a measure for all of the four concepts of TFPG introduced for the 1-1 case. Nevertheless, with multiple inputs and outputs, different formula choices lead to different TFPG measures. This raises the issue of choice among alternative TFPG formulas (Diewert and Nakamura, 2002).

One solution is the use of axiomatic approach to index number choice. This has been a long established part of the tradition of index number theory. An advantage of the axiomatic approach is that it does not depend on assumptions about optimizing behaviour on the part of producers. Also, it is conceptually consistent with the use of commonly available ex post accounting data (Ibid, 2002).

The other approach to this problem is to use algebra and economic theory restrictions to establish that certain index number formulas correspond, by Diewert's "exact" index number approach, to linearly homogeneous producer behavioural relationships that are "flexible" in the sense defined by Diewert that they provide a second order approximation to an arbitrary twice continuously differentiable linearly homogeneous function. Diewert coined the term "superlative" for an index number functional form that is exact for a behavioural relationship with a functional form that is flexible. When the exact index number approach and Diewert's numerical analysis approximation results for superlative index numbers are applied, the a priori information requirements for choosing an index number formula are reduced to a list of general characteristics of the production scenario

In addition, an alternative family of theoretical productivity growth indexes proposed by Diewert and Morrison, namely, the Divisia method, and growth accounting (Note 4) (Ibid, 2002).

\subsubsection{Ratios Approach}

The American Productivity Centre (APC), which is based only on the actual quantities and prices of outputs and inputs over a period of time, is recognized as ratio method in determining productivity (Grason et al, 1987).

The APC analysis suggests that the relative improvement in profitability (output values increasing faster than input values) from Year 1 to Year 2 is entirely attributed to productivity gains and more efficient use of inputs. The APC system uses the actual quantities and prices of both outputs and inputs to compute productivity and price recovery ratios. The technological standards - for labour, material, and overhead - that specify the expected relationship between inputs and outputs in a standard cost system are not exploited under the APC productivity measurement system or, indeed, in any other productivity measurement system. Because the APC measure assumes a constant product mix between periods, it can signal productivity improvements when there have been no productivity improvements in the use of labour, material, or overheads. False productivity improvements can be signalled merely by changes in the mix of output. Unrecognized fluctuations in the prices of outputs and inputs will further distort the productivity measure (Banker et al 1987).

The first step in productivity measurement under the APC system is the computation of the quantity change ratios (QCR) for outputs and inputs .

In the second step, an Aggregate Output Quantity Change Ratio (AOQCR) is computed as a weighted average of the individual output quantity change ratios.

The third one is determining Aggregate Productivity Ratio which is determined based on input Productivity Ratio to output Productivity Ratio.

The last on is defining profitability performance ratio (APPR). The APC system defines the aggregate profitability performance ratio (APPR) as the change in output value divided by the change in input value, indicating that the change in output value was percent higher(lower) than the change in input values ( Ibid ,1987).

\subsubsection{The remain points about productivity measurement and its improvement}

Since the environment is dynamic and is changing all the time, productivity improvement effort must focus on:

- Doing the right things (know "what" should be produced and distributed) by continuously reviewing and identifying changing customers and societal needs; in addition, in order to produce the best possible products and services to satisfy the customer's expectations, economical, social and ecological expectations should be identified as well.

- Doing things right (know "how to do") by constantly improving production and distribution processes to produce and deliver the goods and services in the most efficient way; while at the same time minimizing their negative impacts on internal and external organizational environment (Tolentino, 2004). 
Changes in resource availability and constant changes in customers' needs and expectations, constant innovations in products, processes and organizations are essential for productivity.

Recently, Productivity improvement must focus on value creation rather than on minimization of inputs (Mawson et al 2003, Namazi 2009). Higher customer value is created when the products and services meet customer needs for utility, timeliness, esteem, service, etc. Therefore the following points in productivity measurement should be considered:

- Productivity can not merely be interpreted as an absolute performance or effectiveness. Rather, in productivity the focus is on paying attention to the customers and the community. Before, the productivity has been discussed from management point of view. But today, customer orientation is considered as a main and superlative point of view in productivity discussions.

- The improvement in productivity not only means the reduction in items and consumption costs but also the efficient and effective use of resources in order to produce the consumers' goods and services. Furthermore, the relationship between productivity and progress of society indicates that high levels of productivity are not enough for determining the related number of life quality; rather, other aspects such as social and environmental effects should be considered (Horngren et al 2006).

\subsubsection{Productivity challenges in management accounting}

Some of the general problems arise when we attempt to measure Productivity of an enterprise. In this section, these problems have been reviewed:

1) The lack of information. It means the current input-output accounts will have to be greatly expanded to construct reliable estimates of real value added.

2) What are the various units of observations and what are the productivity indicators to use? A cardinal rule in productivity measurement is that the measurement must support decision making. If increasingly, the productivity performance of an enterprise depends on the supply-chain, value-chain and clusters where it is embedded, whose productivity should be measured?

3) Whatever the unit of observation is, whether a workplace, a unit, a department, a key business process, a value-chain, etc., what are the indexes of productivity and how can be measured? If value is the main output for customer, how is it being going to measured? How do we factor in the social and ecological dimensions of the outputs? How do we factor-in the other aspects e.g. utility, speed, and availability? Similarly, how do we measure inputs? How do we factor in the social and environmental inputs? (toleintino,2004)

4) Separating materials and determining value per unit on marginal product is usually difficult.

In the next section, productivity will be reviewed in business environment.

\section{Productivity and business environment}

In the previous sections we try to present a clear picture of productivity. This section expand productivity concept and explain its relationships with different aspects of business environment, namely, R \&D, Human factors, and Supply chain management.

\subsection{The link between Research and Development activities $(R \& D)$ and productivity}

As Ramsey stated in the definition of productivity, there is a meaningful relationship between productivity and Research and development (R\&D) expenditures (Ramsey, 2006). When looking for evidence of technological exhaustion, a common approach taken in the literature is to look for a decline in the R\&D elasticity in production function or total factor productivity regressions. Focusing on R\&D inputs avoids the potential pitfalls of measuring invention output (Lanjouw J. and Schankermann M., 2002).

Economic theorists have accepted the positive link between technological changes, Productivity and economic growth for a long time. Process innovation provides opportunities for cost reduction. Product innovation enhances either the range of available intermediate inputs for the production process, increases the real output, or increases the availability of consumer products with corresponding welfare gains. Indeed, in modern economies, the inputs of capital and labor alone cannot account for a large part of output growth (Solow, 1957).-

\subsection{Human factors in productivity}

Working in competitive market is a factor that helps companies to develop. On the other hand, their changes will be increased. Regarding this issue, managers must identify the factors that cause environmental changes and instability, and then choose appropriate strategies to reduce the undesired effects of these factors. These 
strategies can include creating organizational relationships (through, ownership, the official combination, and Special participation ...) and applied to control the territory or the environment (through change in scope, political activities, and commercial councils...). Organizational relations, as a determining factor in improving the efficiency, have been always in the focus. For developing productivity improvement technology, ability of manpower and the way of using their talents in creating new technology must be considered (Tolentino, 2004 and Sink, 1985).

Human resources system can regulate the production system of an organization based on its structure and market activities. This function cannot be achieved by mechanical forces and even artificial intelligence completely. Motivation, processing power and consistency are essential elements for survival of organizations and these elements can only be found in human force (man power). The roles of human and social capitals in the creation of productivity and competitive advantages are undeniable. In addition, human resources management and its development have been one of the most important parts of any business organizations.

It is important to know that production process and its improvements need to be observed on a continuous basis in a way that enables staff to improve their skills and show their competence. In order to fulfill these goals, by emphasizing on organization earning processes, cooperation and team work within organization must be improved.

\subsection{Supply chain management and productivity}

Supply chain management (SCM) is the term used to describe the management of the flow of materials, information, and funds across the entire supply chain, from suppliers to component producers to final assemblers to distribution (warehouses and retailers), and ultimately to the consumer (Johnson et al, 1999). Supply chain management has generated much interest in recent years for a number of reasons. Many managers now realize that actions taken by one member of the chain can influence the profitability of all others in the chain Firms are increasingly thinking in terms of competing as part of a supply chain against other supply chains, rather than as a single firm against other individual firms. In addition, as firms successfully streamline their own operations, the next opportunity for improvement is through better coordination with their suppliers and customers.

In the next section, some major researches in productivity area will be examined.

\section{Research Methodology}

In order to bring theoretical concepts to practice, some empirical researches have been reviewed in this section.

The production of knowledge depends very much on the techniques for collecting, analyzing, and interpreting data and on the way they are applied. This study is one of content analysis and an archival methodology (Simon, 1980) .The time period of 1991-2010 was investigated to obtain enough information related to our topic and multiple data sources were employed. We gathered 32 empirical studies from Canada, Germany, Iran, India, Japan, South Korea, Spain, U.K and U.S.A, which maintains a large collection of dissertations. Because of in an era of tight budgets and increased outsourcing, getting of good measure of an organization's productivity is a persistent management concern. Unfortunately, experience shows that no single productivity measure applies in all situations for all purposes. Instead, organizations must craft productivity measures appropriate to their processes and information needs (Card, 2006). In this section, productivity measurement methods in the world have been reviewed. With reviewing studies in this countries are identifies that ratio approach and determining models with regression and OLS analysis are more applied and accepted. Also change of GDP is important in productivity's comparison among countries and tries to eliminate effects of changes in price. In Table (2) and (3) the major researches about productivity measurement base in countries, discussed in this section are summarized, and in the continued, these researches reviewed in actual examples.

\subsection{Canada}

There are many studies in Canada which is focused productivity measurement in a specific industry with analyzing details to determine its output, input variables, production processes and identifying important productivity drivers and Trends to determine challenges in improving productivity for example considered the evolution of productivity life insurance industry (Bernstein J. I. 1999), banking sector (Fixler and Zieschang, 1999), Construction Sector (CSLS (Note 5) Research Report 2001), Forest Products (CSLS Research Report, 2003) Service Industries (Rao et al, 2004) the Coal Mining Industry (Smith J. 2004) ,and the Health Care Sector(Sharpe et al 2007) .Other researches' are international comparisons of productivity between Canada and other Countries (e.g. US). for instance survey relationship between Productivity and Real Wage Growth in Canada and OECD Countries (Sharpe, Arsenault, and Harrison, 2008) Comparison of Productivity Trends in Canada and U.S. (Sharpe. A 1999, CSLS Research Report 2004 and Gu and Lafrance, 2010) these case studies 
often make use of data for individual establishments and benchmarking techniques to compare performance. The data on multifactor productivity (MFP) growth and labor productivity growth produced by the official statistical agencies in Canada (Statistics Canada) and the United States (Bureau of Labor Statistics, or BLS(Note 6) send mixed signals regarding the comparative evolution of living standards in the two countries. Since the early 1980s, Statistics Canada's MFP growth measures for the business sector indicate that the Canadian economy has outperformed the US economy while labor productivity data produce a reverse picture. This is the so-called Canada-US Productivity Paradox (Coulombe, 2000). In a study, Coulombe investigated the productivity paradox with an analysis of Canadian and US business sector productivity data since 1961. The main finding of his analysis was that business sector MFP growth estimates provided by Statistics Canada in March 1999 are neither consistent over time nor comparable to U.S. estimates. The analysis identified three significant problems with the methodology used by Statistics Canada for estimating MFP growth. His conclusion was that Statistics Canada should thoroughly revise its methodology for estimating the capital stock and measuring changes in labor force composition. This paper proposed methodological changes to address these problems. In trend of these researches, Baldwin et al. (2010) review Canada productivity structure and methods of determining it. therefore Canada productivity trends are recognized they describe how can be used to construct various estimates of productivity in a way that are used to produce these estimates and the robustness of the estimates relating to alternate assumptions used in developing the analytical estimates of productivity growth.

\subsection{Germany}

In this country, most of researches are comparative ones that productivity of Germany and other countries such as United States and United Kingdom. For example, Broadberry and Burhop provided a new benchmark estimate of comparative Germany/U.K. labor productivity in manufacturing for circa 1907, and experiments with alternative German manufacturing production indices for time series projection from a circa 1935 benchmark. They concluded that Labor productivity in manufacturing was about the same in Germany and Britain from the late nineteenth century to World War II, supporting the earlier findings of Broadberry. Starting from Broadberry and Fremdling's (1935) benchmark estimate of comparative labor productivity in manufacturing, they projected backwards to 1871 and forwards to 1938 using new time series data of Germany's manufacturing output. They supported their finding for the pre-World War I period using new income data from Burhop and Wolff. Using these data, they reworked Fremdling's income-based estimate of comparative labor productivity in manufacturing. They found broadly equal levels of manufacturing labor productivity in the two countries throughout the period 1875-1913, as suggested by their output-based estimates. Overall, they were able to reconcile most of the existing time series and benchmark estimates of comparative Germany/U.K. labor productivity in manufacturing before World War II.

In addition, there are some researches that solely study productivity in Germany. For instance, in July 2009, Helmut Mayer presented a paper about measurement of Energy productivity in Germany. In this study, he stated that, "The decomposition analysis is a useful tool in the analysis of energy consumption. It enables the determination of energy productivity for industries without a bias through a changing composition of industries. By using additional data sources on socio-economic variables household's energy consumption could be analyzed in more detail in order to determine the drivers of energy consumption. Thus the decomposition analysis enables valuable background analysis on sustainable development indicators".

\subsection{India}

In India, Most of the empirical studies in field of productivity focused on the growth in the TFP and TFPG in the manufacturing sectors., like Brahmananda (1982); Ahluwalia(1991); Balakrishnan and Pushpangadan,(1994); Majumdar, (1996); Rao(1996); Pradhan and Barik(1999); Trivedi, Prakash and Sinate, (2000); Unel (2003) ; Goldar (2004);Virmani(2004) and Ako (2005)and Saxena, Thakur, and Singh (2009) .

These studies show that decline in the total factor productivity growth (TFPG) till 1970s, with a turnaround taking place in mid-1980s. For instance, Rodrik and Subramanian (2004) argued that the transition to high growth phase occurred around 1980 - a full decade before economic liberalization - due to pro-business policies that adopted during the 1980s. Another Study by Unel (2003) and Tata Services Ltd (2003) found TFPG ratio acceleration in the 1990s. On the other hand, Goldar (2004) and RBI (2004) found a deceleration in the TFPG in india. Regarding acceleration in TFPG, the results of researches (such as Krishna and Mitra, 1998; Chand and Sen, 2002; Das, 2003; and, Topalova, (2004)) showed that trade liberalization since 1991 has had a positive impact on the TFPG in India. More recently, Virmani (2004) has attempted to measure the TFPG for the Indian economy as a whole and his estimates suggests that the TFPG has followed a V-shaped pattern since independence, with near flattening from the late 1980s. 
In comparison productivity with other countries, Ark and Inklaar (2005) shows that labor productivity growth in India in recent years is better than in Germany, the United Kingdom and the United States.

In recent years, application of data envelopment analysis (DEA) approach to measure the Productivity performance is popular for example Saxena et al (2009) survey productivity in ndia's telecommunications sector. This study applies a data envelopment analysis (DEA) approach to measure the magnitude of performance differences between leading telecom operators in terms of their marketability and Profitability. The analysis has been conducted employing non parametric techniques, based on linear programming, and called Data Envelopment Analysis (DEA) which allows measuring the Malmquist Total Factor Productivity.

\subsection{Iran}

Most of the researches in field of productivity focused on productivity measurement and compared Productivity trends over the periods are given in manufacturing sectors, such as Sadeghi, M. and Gholami (2003) measured the total factor productivity (TFP) of the rural small industries in Isfahan province with comprising six types of industries: food, textile, metal, non-metal mineral, chemical, and cellulose. Among the166 rural small industries sponsored by Jihad-Agriculture Organization of Isfahan (Iran) in 2001, 60 plants were selected. The analytical part of this research consisted of two sections. In the first section, the TFP of the rural

small industries was established by applying Cobb-Douglas production function in which the value of the plant production was the dependent variable and the investment costs, total hours of labor, costs of raw materials, and the costs of energy and water were the independent variables. Factors affecting TFP in this research were analyzed in the second section. The results of the first section showed that the TFP of food industries was higher than that of other types of industries and there was no significant difference between the TFP of textile, metal, non-metal mineral, chemical and cellulose industries. The results of the analysis for determining the factors affecting the TFP showed that the existence of a research section in the plant, the insurance of the employees and the mean of the number of employees' children had a positive effect on the TFP. But, the level of the education of the production workers, the area of the plant buildings, and the number of the days off in plant had negative effects.

In another study, Azar and Moetameni (2004) proposed a comprehensive model by using Data Evaluation Analysis (DEA) models and interfering time factor in those models in order to evaluate production companies' performance in Iran. They concluded that, among DEA models, Charnes, Cooper and Rhodes (CCR) model is better than the other ones especially from evaluation ability and realistic aspect. Moreover, Oraee et al (2010) tried to define productivity accurately and hence simplify its measurement. In this study the productivity of Eastern Alborz Coal Mines in Iran has been calculated for 7 years (2001-2008). At this point, by using the ratio of output (as monetary unit) per total inputs, the total productivity is calculated. Then by using the inputs of personnel, energy and capital, the partial productivity of the EACM are calculated. Finally, the resulting values and the component models are subject to analysis. These results are examined in terms of practicability. It is shown that the method prescribed is a pragmatic approach in all similar system situations and also trend of the personnel productivity changes and the capital productivity are compatible with the total productivity.

\subsection{Japan, South Korea, and Taiwan}

In these countries, productivity measurement is based upon guidance of Asian Productivity Organization(APO), total productivity factor is calculated, for instance Singh and Trieu(1996), by using a consistent methodology and data sets, present total factor productivity growth (TFPG) calculations for Japan, South Korea and Taiwan. Actually, they reassessed the productivity growth experience of Korea and Taiwan, as compared to Japan and previous work on Latin American countries. They concluded that Korea and Taiwan's experience is not simply explained by factor accumulation and also Korea and Taiwan's higher growth rates for this period, again using Japan as a benchmark, can be attributed to higher input growth, in both capital and labor. All three countries show similar TFPG rates, but Japan's TFPG represent a higher fraction of output growth than in the case of Korea and Taiwan. Nakano M. and Managi S.(2010) measures Japanese productivity from 1991 to 2002 and examines the factors that have impact on productivity with data envelopment analysis (DEA) and the Luenberger productivity indicator, research findings show that productivity decreased during investigation period.

In Korea, Don Oh Choi, Ji Soo Kim (2005) propose models which employ a partial factor productivity measure with one input factor and some output factors of productivity measurement and evaluation of an R\&D organization. The results obtained using this model can provide a criterion for incentive pay allocation among organizational units for top management. An illustrative application is shown for five military R\&D centers and an evaluative comparison is made among centers. Benefits of these models include usefulness in relative evaluation among units in other organizations if the regression equations are properly derived. Liu et al (2010) 
also study the relationship between workforce composition and firm's productivity in three measures. The results of this research show that steel and transportation industries outperform in productivity. They concluded that economic incentives and market competition both play important roles in the firm's performance.

\subsection{Spain, Switzerland and Denmark}

Determining total factor of productivity (TFP) is important issue which the most of Spanish researchers pay attention to it, principal purposes for these calculations and measurements are survey of trends and national economic a comparison with economic World. For example, Fernandez et al (1995) measured total factor of productivity (TFP) in Spanish agriculture during the period 1962 to 1980, they concluded highest rates for the agricultural sector achieved in the world during 1970 to 1980, but TFP growth slowed in the 1980s. This appears to coincide with Spain's entry into the European Common Market in the 1980s. Another research in Spain was done by Mesonada (1998) who used capital data from Farm Account Data Network (FADN) for measuring agricultural total factor productivity and calculating multifactor productivity index. He concluded, in order to analyze the agricultural private sector the capital data that can be obtained from the FADN, in general terms, have better quality than the macroeconomics data. In addition, these data are very useful for increasing the level of desegregation on the productivity analysis and it should be important to discuss the procedures involved in constructing the capital input index. Thus FADN and the Eurostat data about wages, input and output prices if joint with carefully treatment provide a reasonable homogeneous set of data that can be used in approximation of the total factor productivity comparisons. Aguirregabiria and Alonso-Borrego (2008) evaluates productivity of a labor market reform in 2356 Spanish manufacturing firms for the period 1982-1993.they find important effects on employment and job turnover, on productivity and value of firms. Labor Contracts and Flexibility: Evidence from a Labor Market Reform in Spain. In year- 2010 Alonso-Borrego) use of the control function approach, measure of TFP is obtained from the residual of the estimation of the technologies of production and estimate of total factor productivity (TFP) by plugging in the estimated technological parameters in the production function to analyze the evolution of productivity and effects of Spanish firm (manufacturing and services companies) behavior and institutional conditions in productivity between 1983 and 2006; they have found that the share of temporary employment tends to reduce productivity, also show that increases in competition lead to productivity improvements and provided evidence about productivity, and its relation with firm behavior and regulatory conditions And told t" the establishment level of productivity, it is essential to understand many features of productivity growth that have consequences at the Aggregate level."

Rudolf B. and Zurlinden M. (2010) analyzed sources of economic growth in Switzerland for the period 1991-2006. Their findings show that the estimated growth in multi-factor productivity is decreased in comparing with previous studies about Switzerland productivity,

Parrotta et al (2010) analyzed the effects of diversity in cultural background, skills and demographic characteristics in total factor productivity (TFP) for the years 1995-2005 in Denmark firms and investigated the effect of labour diversity on productivity at three dimensions: cultural background, skills/education and demographics with the following of Wooldridge (2009) to simultaneity and endogeneity problems in the computation of firm TFP. They Also use of Sensitivity analysis to check whether there is any difference in the effect of diversity on TFP across different industries and finally find evidence that labour diversity in skills/education significantly enhances firm performance

\subsection{United Kingdom}

The quest for productivity improvements in the UK has been increased dramatically over the last decade and many researches' have been performed in this area, namely, Latham (1994), Egan (1998), Chan and Kaka (2003), Atkinson (2005), Martin (2008) and Peñaloza et al. (2010). In continues, some of these researches have been described.

Chan and Kaka (2003) studied 400 UK contractors in order to understand the measure of construction labor productivity and found that among 77 respondents, more than half of them did not monitor productivity levels at the project level. Furthermore, one third of those who claim to do it actually did it based their judgment of productivity on gut feeling and experience of dealing with contract schedules.

Atkinson (2005) survey outlines a number of principles covering the measurement of outputs, inputs and productivity. One particularly significant point is that the review strongly recommends that, in principle, measures of output growth should take account of quality change. Also, and specifically with regard to productivity, the review states: Outputs divided by inputs provides a measure of productivity change.

Another research in both labor productivity and total factor productivity (TFP) among firms in U.K was performed 
by Martin (2008). He surveyed firm level productivity analysis among firms in narrowly defined sectors' classes and offered accounting for imperfect competition matters in order to estimate the persistence of TFP. In addition, he found that there is a negative relationship between competition and productivity dispersion. Actually, the main point in this research was reviewing productivity levels in deferent industries (such as foods, chemical, plastic, and mineral, automobile, steel) during 1980 until 2000. Moreover, Peñaloza et al. (2010) present latest estimates of UK healthcare productivity change in continuing work to incorporate recommendations of "the Atkinson Review: Final Report Measurement of Government Output and Productivity for the National Accounts With multi-factor productivity growth".

\subsection{United stated}

As stated in previous sections, in USA, measurements models have focused on ratios approach. Although there was some old fashion models, namely Bureau of Labor Statistics (BLS), which have been used until mid 1990s. The BLS work has focused on development of time series of outputs, factor inputs, and other variables considered important for the measurement and analysis of productivity trends. These variables have been developed at the aggregate level and also for numerous individual industries. With the exception of the Hours at Work Survey, these time series have been developed from data published by other programs of the BLS and by other government statistical agencies (Dean and Harper, 1998).

Many studies have been performed in field of productivity in industries. For instance

Gullickson W. (1995) Measured productivity of industries that provided important insights into technological change and price increases. This article has presented evidence on the recovery of productivity growth in manufacturing sector in 1949-1992s, in spite of price change through the postwar period. Furthermore, in this article, the form of productivity measures for industries has also been discussed. In recent years, Bosworth and Triplett (2007) by using output in the numerator, rather than value added and also computed growth accounting equations for each of 24 goods industries and 33 services industries showed that strong MFP growth in the services sector changed American economic performance after 1995. Their results show that during the years of slow aggregate productivity growth (1973-1995), the services industries were marked by productivity stagnation; after 1995, services productivity accelerated strongly and LP and MFP rates of services sector growth more than doubled. Services sector acceleration substantially exceeded the more modest productivity accelerations in the goods-producing sector. another research about trend productivity have been done by Harper,M et al (2010) for farm and nonmanufacturing industries, compound annual rates of change in period 1987 to 2006. Findings of this research show that a number of negative growth rates, some of which reflect earlier findings, and a few highly positive growth rates have been occurred. The growth rates presented also reflect the well-known story of the bump-up in productivity that occurred in the late 1990s and continued through the first decade of the 2000s. Over the examination period, the average annual compound multifactor productivity growth rates for 42 nonmanufacturing industries were positive, or zero for 25 of the 42 industries, and negative for 17 industries. Of the 17 industries reporting negative productivity over the 20 -year period, 2 recorded declines of more than 1.0 percent per year.

\subsection{Other studies about productivity in the world}

Also in this section productivity studies have been reviewed at country or inter-country level,

Numerous studies have been carried out at the international level that compared administrative efficiency and performance internationally. Yearly reports of European Central Bank, World Bank, Asian productivity organization (APO), The Centre for the Study of Living Standards (CSLS), World Employment Report and International Labour Organization have such these studies. Also in 1990, in the United Stated, The McKinsey Global Institute (MGI), established in Washington, DC in order to analyze international productivity levels from both economic and management perspectives and compares productivity in other countries (Andrew Sharpe, 2010). In MGI, researchers use microeconomic analysis on a sector-by-sector level to study ultimate effects of industry decisions on national productivity. MGI classified productivity drivers into three areas: competitive, managerial and demand factors for example in France, Germany and U.S productivity gap are reviewed (Farrel et al, 2003).

\section{Conclusion}

Modern business and management accounting literature insists on the use of non-financial criteria as means to overcome the deficiency of financial standards and in fact believes that non-financial criteria must be used along with financial criteria. Hence Banker and Kaplan suggested the use of some criteria like productivity, quality, lead production, construction and supply exploited to improve the measurement of the performance. Productivity and quality are two sides of the coin, because the senior management and individuals within the organization 
understand the concept of productivity and quality is best understood by customers; so, considering one without another is not possible. Most known commercial units, believe in productivity as a foundation of success, and the output of such a foundation is quality. Productivity Measurement and the standard cost system can be used as a supplement for performance assessment. Standard cost system and Variance analysis are periodic approaches in which the actual items and the budget items (standard) are compared to each other. Therefore, in combination with productivity measurement system (a beyond periodic system), which compares the actual cost of all courses with successful past events, and by separating profitability changed in to three sections, Changes in sales activities (including size and composition inputs), changes in consumption and changes in price recycling, a comprehensive explanation of profitability can be reached.

In addition, There are many Models and methods of measuring the level of the productivity which are offered by economists, engineers, project managers and mathematicians, namely: Index approach, production function, utility approach, financial ratio approach, unit cost approach and mathematical models and among these approaches and models, Indexes, ratios and data envelopment analyses are more accepted and applied in Productivity measurement.

Furthermore, productivity relationship can be expanded to the different points of business environment. Finally, empirical research shows that a unique method cannot be prescribed for productivity measurement. Different countries use different methods in different situations.

\section{References}

Aguirregabiria Victor and Cesar Alonso-Borrego. (2008). Labor Contracts and Flexibility: Evidence from a Labor Market Reform in Spain, Universidad Carlos III de Madrid - Department of Economics, Working Paper Series, ssrn.156451.

Alonso-Borrego Cesar. (2010). Firm Behavior. Market Deregulation and Productivity in Spain American accounting association,

Committee on Concepts and Standards for Externals Financial Reports. (1977). Statement on Accounting Theory and Theory Acceptance (SATTA), Sarasota .

Andrew Sharpe. (2010). Unbundling Canada's Weak Productivity Performance: The Way Forward, CSLS Research Report.

Ark, Bart van. (2005). “Europe's Productivity Gap: Catching Up or Getting Stuck?” Paper presented at International Symposium on Productivity, Competitiveness and Globalization at Banque de France, Paris on November 4, 2005.

Baldwin John, Gu Wulong and Macdonald Ryan. (2010). Integrated Productivity Accounts:Contributions to the Measurement of Capital, The Canadian Productivity Review, Statistics Canada Catalogue no. 15-206-X, no. 027.

Banga, Rashmi and Bishwanath Goldar. (2004). Contribution of Services to Output Growth and Productivity in Indian Manufacturing: Pre and Post Reforms. Working Paper No. 139, ICRIER

Banker R., Datar S., and R. Kaplan. (1987). Productivity Measurement \&Management Accounting. Journal of Accounting, Auditing \& Finance, 4, 528-554

Blocher E, stout D, Cokins G and Chen K. (2008). Cost management, a strategic Emphasis. Fourth ed.England: Mc Graw Hill.

Broadberry S., and Burhop C. (June 2007). Comparative Productivity in British and German Manufacturing before World War II: Reconciling Direct Benchmark Estimates and Time Series Projections. The Journal of Economic History, Vol. 67, No. 2, 315 -348.

Chan, P and Kaka, A. (2003). Construction labour productivity improvements. In: Aouad, G and Ruddock, L (Ed.) Proceedings of the third international postgraduate research conference, 3 \& 4 April, Escola Superior de Actividades Imobiliárias (ESAI), Lisbon, 583 - 598.

Charnes, A., Cooper W., and E. Rhodes. (1978). Measuring the efficiency of decision-making units. European Journal of Operational Research. 2, 429-444.

Comin, D. "Total Factor Productivity. (2008). American Economic Review, 96 (3), 523-551.

Coulombe Serge. (2000). Three Suggestions to Improve Multi-Factor Productivity Measurement in Canadian Manufacturing, CSLS Conference on the Canada - U.S. Manufacturing Productivity Gap.

Diewert E. W., Nakamura A., and Sharpe A. (1999). Special Issue on Service Sector Productivity and the 
Productivity Paradox. Canadian Journal of Economics, Volume 32, No. 2.

Diewert W.E., and A. Nakamura. (2002). The measurement of aggregative total factor Productivity growth, OECD Productivity Manual, Elsevier Science Handbook of Econometrics, 6, 45-79.

Etemadi H. (2001). The use of management science techniques in the management accounting information. Modares university journal, 5 (2), 23-39.

Fernandez M. Carmen, A. Casimiro Herruzo and Robert E. Evenson. (1995). Measurement of total factor productivity of Spanish agriculture. Oxford Development Studies, Volume 23, Issue 1, 63 - 71.

Fremdling, Rainer. (1991). Productivity Comparison between Great Britain and Germany. Scandinavian Economic History Review, 39, no. 1 28-42, 1855-1913."

Governor V.S. (2005). Importance of Productivity in India, Reserve Bank of India, at the Annual, Conference of Indian Economic Association held on December 27, 2005 at Andhra University, Visakhapatnam.

Grason C.J and Jr. Chairman. Rational ship of quality and productivity. American Productivity center (APC), number 65 of productivity Brief, 1-5.

Gu Wulong and Lafrance Amélie. (2010). Productivity Growth in Canadian and U.S. Regulated. Industries, international Productivity monitor, No 19.

Gullickson W illiam. (1995). Measurement of productivity growth in U.S. Manufacturing Monthly Labor Review, July 1995, 13-37

Helmut Mayer. (2009). Environmental-Economic Accounting (EEA) reporting on sustainable development indicators in Germany: measurement of energy productivity, presented at the EMAN Conference 2009: "Environmental Accounting and Sustainable Development Indicators" 23 - 24 April 2009, Prague (Czech Republic)

Horngren, C. T., Foster, G., \& Datar, S. (2006). Cost accounting: $A$ managerial emphasis. $\left(12^{\text {th }}\right.$ ed.). New Jersey: Prentice-Hall, USA.

Jack Triplett and Barry Bosworth, Productivity in the U.S. Serv-ices Sector (Washington, DC, The Brookings Institution, 2004-2007); and "Is the 21st Century Productivity Expansion Still in Services? and What Should Be Done about It? " presented at the January 2007 meeting of the American Economic Association, WashingtonDC.

Johnson M., \& David F. Pyke. (2000). Supply Chain Management: Innovations for Education, in POMS Series in Technology and Operations Management, Production Operations Management Society.

Kato Atsushi. (2005). "Product Market Competition and Productivity in Indian Manufacturing Industry", Working Paper Series No.E/263, Institute of Economic Growth

Kuhn, T. S. (1996). The Structure of Science Revolution. Third ed. Chicago, IL: The University of Chicago Press.

Liu Jin-Tan; Meng-Wen Tsou and Ping Wang. (2010). Workforce Composition and Firm Productivity: Evidence from Taiwan. Economic Inquiry, Vol. 48, Issue 4, pp. 1032-1047, October 2010.

Makiko Nakano and Shunsuke Managi. (2010). Productivity measurement with CO2 emissions in Japan. Pacific Economic Review, Volume, 15, Issue 5, pg 708-18.

Martin Ralf. (2008). Productivity Dispersion, Competition and Productivity Measurement, Centre for Economic Performance, London School of Economics and Political Science, CEP Discussion Paper No 692.

Mawson P., I.K. Carlaw and McLellan N. (2003). Productivity measurement: Alternative approaches and estimates. New Zealand Treasury, Working Paper 03/12.

McKinsey and Company Canada. (2008). Breaking Away from the Pack: Enhancing Canada's Global Competitiveness. McKinsey and Company.

Mesonada Carlos \& San Juan. (1998). Capital data for productivity measurement, Departamento de Economia, Universidad Carlos III de Madrid, Spain, Working Paper 98-84, Economics Series 24.

Michael J., Harper, Bhavani Khandrika, Randal Kinoshita and Steven Rosenthal. (2010). Nonmanufacturing industry contributions to multifactor productivity 1987-2006, Monthly Labor Review, June 2010, 16-31.

Namazi. M. (2009). Performance focused ABC. Cost Management informs Global, 34-45.

Oraee Kazem, Navid Hossein, Mohammadreza Soltani and Mehdi Amirafshari. (2010). Productivity improvement from economic concept to an engineering tool, 2010 Underground Coal Operators' Conference, 11

- 12 February 2010, The AusIMM Illawarra Branch 
Parrotta Pierpaolo, Pozzoli Dario and Pytlikova Mariola. (2010). Does Labor Diversity Affect Firm Productivity?, Department of Economics, Aarhus School of Business, University of Aarhus Working Denmark, paper 10-12.

Peñaloza Maria-Cristina, Hardie Michael; Wild Richard and Mills Katherine. (2010). UK Centre for the Measurement of Government Activity Public Service Output, Inputs and Productivity: Healthcare, The Office for National Statistics. [Online] Available: www.opsi.gov.uk .

Pinsonneault Alain and Kenneth L. Kraemer. (1992). Survey researches methodology in management information system: an assessment, École des Hautes Études Commerciales Montréal, Canada, 1992.

Ramsey R. (2006). Improving Profitability through People and Organizational Excellence, Asian productivity organization. [Online] Available: www.apo-tokyo.org/productivity

Rudolf Barbara and Mathias Zurlinden. (2010). Productivity and Economic Growth in Switzerland 1991-2006, Swiss Journal of Economics and Statistics, Volume 146, Issue III, pg 577-600.

Sadeghi, M., and gholami. (2003). Analysis of Affecting Total Factor Productivity of Rural small Industries" Sponsored by Jahade-Agriculture Organization of Isfahan province, Seventh ERC/METU International Conference in Economics, Ankara, Turkey Scandinavian Economic History Review 39, no. $128-42$.

Saxena Vineeta (Nigam), Thakur Tripta and R.P.Singh. (2009). Productivity analysis of the telecommunications sector in india. International Journal of Engineering and Technology, Vol.1 (2), 2009, 40-45

Simon, H. (1980). The behavioural and social sciences. Sciences, 209, July 4, 72-78.

Sink, Scott D., and Thomas C. Tuttle, Planning and Measurement in Your Organization of the Future, (Industrial Engineering and Management Press, (01/89), pg 13-31.

Solow, R (1956). A Contribution to the Theory of Economic Growth. Quarterly Journal of Economics, No70 (1), pg 65-94

Tolentino, A. L. (2004). New Concepts of Productivity and its Improvement, Presented at the European Productivity Network Seminar, A review of productivity improvement in Europe in the past 5 years, issues \& scope for the future", Budapest, 13 -14 May 2004.

Virmani, Arvind. (2004). Sources of India's Economic Growth: Trends in Total Factor Productivity", Working Paper No. 131, Indian Council for Research on International Economic Relations, New Delhi

\section{Notes}

Note 1. for more information, see the Statement on Accounting Theory and Theory Acceptance, 1977,5-21

Note 2. Total Factor Productivity (TFP) is the portion of output not explained by the amount of inputs used in production. As such, its level is determined by how efficiently and intensely the inputs are utilized in production. At business cycle frequencies, TFP is strongly correlated with outputs, products and inputs (as hours work, Materials consumed and overhead absorbed).TFPG is used to measure productivity growth toward productivity changes in target years.

Note 3. For the 1-1 case, the ratio of output produced (y) to input used (x) in period $t$ is our measure for TFP for period $t$; that is, we define:

$$
\operatorname{TFP}=\left(\mathrm{y}_{1}^{\mathrm{t}} / \mathrm{x}_{1}^{\mathrm{t}}\right)=\mathrm{a}^{\mathrm{t}}
$$

And, for the 1-1 case the measures for all four of the concepts for TFPG reduce to: (For more information, see Diewert and Nakamura, 2002.)

$$
\mathrm{TFPG}=\left(\frac{\mathrm{y}_{1}^{\mathrm{t}}}{\mathrm{y}_{1}^{\mathrm{s}}}\right) /\left(\frac{\mathrm{x}_{1}^{\mathrm{t}}}{\mathrm{x}_{1}^{\mathrm{s}}}\right)
$$

Note 4. For more information, see Diewert and Nakamura, 2002.

Note 5. The Centre for the Study of Living Standards in Canada

Note 6. For more information about BLS, Sea U.S. part

Table 1. Productivity Vs Quality 


\begin{tabular}{|c|c|c|}
\hline View & Productivity & Quality \\
\hline Organization & Efficiency of production process & $\begin{array}{c}\text { understand ,analysis and improve performance } \\
\text { (finally decrease of losses ) }\end{array}$ \\
\hline Management & Based on increasing quality & Being analyzed the boundaries of the efforts \\
\hline Customer & Distinctly not Recognize & Recognize by using of company products \\
\hline
\end{tabular}

Note: in this table compares the productivity and the quality from the organization, customers and management's point of view, we identify quality when use or hear about product of company and so, we recognize poor quality when it is absent such as using of the term quality to emphasize both the technological and value dimensions of an innovation.

Table 2. Summary of the major researches about productivity based upon measurement base and results

\begin{tabular}{|c|c|c|c|}
\hline Country & \multicolumn{2}{|c|}{ Productivity Measurement Base } & Researchers \\
\hline$\underline{\text { Canada }}$ & $\begin{array}{l}\text { Multi-Factor } \\
\text { productivity ( ratio } \\
\text { and index analysis) }\end{array}$ & $\begin{array}{l}\text { Using of Index approaches and Ratio analysis } \\
\text { for registering price changes, identifying } \\
\text { important productivity drivers and Trends to } \\
\text { determine challenges in improving productivity }\end{array}$ & $\begin{array}{c}\text { Coulombe (2000) } \\
\text { CSLSResearch Report(2003) } \\
\text { Sharpe et al (2008), Gu and } \\
\text { Lafrance(2010) }\end{array}$ \\
\hline \multirow[t]{2}{*}{ Germany } & $\begin{array}{l}\text { Productivity } \\
\text { Measured by the } \\
\text { relation Gross } \\
\text { Domestic Product } \\
\text { (GDP) to the } \\
\text { physical use of The } \\
\text { resource. }\end{array}$ & $\begin{array}{l}\text { Index approaches with using if decomposition } \\
\text { analysis to the determining } \\
\text { Productivity factors such as the scale effect, } \\
\text { composition effect, - the intensity effect }\end{array}$ & Helmut Mayer(2009) \\
\hline & $\begin{array}{l}\text { Time series } \\
\text { changes in GNP } \\
\text { and other indexes }\end{array}$ & $\begin{array}{l}\text { Having initially provided a set of benchmarks } \\
\text { that conflicted with } \\
\text { Time series projection between two periods with } \\
\text { benchmarking. }\end{array}$ & Broadberry and Burhop (2007) \\
\hline India & $\begin{array}{l}\text { Luenberger } \\
\text { productivity index } \\
\text { and DEA analysis }\end{array}$ & $\begin{array}{l}\text { measure productivity change in a joint } \\
\text { production model, } \\
\text { with a vector of market and non-market outputs } \\
\text { using } \\
\text { production frontier analysis } \\
\text { This approach uses the Luenberger productivity } \\
\text { index, } \\
\text { which is the dual to the profit function and does } \\
\text { not require } \\
\text { the choice of an input-output orientation }\end{array}$ & $\begin{array}{l}\text { Shunsuke Managia, , Pradyot } \\
\text { Ranjan Jena(2007),Kumar } \\
\text { (2006), (Chambers et al.,1996), }\end{array}$ \\
\hline \multirow[t]{2}{*}{ India } & $\begin{array}{l}\text { Measurement of } \\
\text { output to inputs } \\
\text { ( Ratio analysis) }\end{array}$ & $\begin{array}{l}\text { The official series on Index Number of } \\
\text { Wholesale Prices in India to identify production } \\
\text { function. }\end{array}$ & $\begin{array}{l}\text { Rashmi Banga Bishwanath } \\
\text { Goldar(2004) }\end{array}$ \\
\hline & $\begin{array}{l}\text { Total factor } \\
\text { Productivity } \\
\text { (ratio analysis ) }\end{array}$ & $\begin{array}{l}\text { Measurement Total Factor Productivity of Rural } \\
\text { small Industries And analysis for determining } \\
\text { the factors affecting the TFP. }\end{array}$ & $\begin{array}{c}\text { Sadeghi, M. and Gholami, (2003) } \\
\text { and Oraee, Hossein, Soltani, and } \\
\text { Afshari (2010) }\end{array}$ \\
\hline
\end{tabular}




\begin{tabular}{|c|c|c|c|}
\hline Country & \multicolumn{2}{|c|}{ Productivity Measurement Base } & Researchers \\
\hline Iran & $\begin{array}{l}\text { Productivity } \\
\text { measurement in } \\
\text { production } \\
\text { companies with } \\
\text { DEA models }\end{array}$ & $\begin{array}{l}\text { Proposed a comprehensive model by using Data } \\
\text { Evaluation Analysis (DEA) models in those } \\
\text { models in order to evaluate production } \\
\text { companies' performance. }\end{array}$ & Azar and Motamene (2004) \\
\hline $\begin{array}{l}\frac{\text { Japan, }}{\text { South }} \\
\frac{\text { Korea }}{\text { Taiwan }}\end{array}$ & $\begin{array}{l}\text { total factor } \\
\text { productivity growth } \\
\text { (TFPG) and partial } \\
\text { factor productivity } \\
\text { measure }\end{array}$ & $\begin{array}{l}\text { Productivity measurement and evaluation } \\
\text { models with application to a military R\&D } \\
\text { organization and compare among Growth } \\
\text { productivity in these countries measures and } \\
\text { impact on productivity with data envelopment } \\
\text { analysis (DEA) }\end{array}$ & $\begin{array}{c}\text { Nirvikar Singh and Hung } \\
\text { Trieu(1996), Don Oh Choi, Ji Soo } \\
\text { Kim (2005), Managi S.(2010), Liu } \\
\text { et al (2010) }\end{array}$ \\
\hline $\begin{array}{l}\text { Spain and } \\
\underline{\text { Denmark }}\end{array}$ & $\begin{array}{l}\text { Measurement of } \\
\text { total factor } \\
\text { productivity }\end{array}$ & $\begin{array}{l}\text { calculating multifactor productivity index and } \\
\text { intertemporal TFP, under the maintained } \\
\text { assumption of producer cost minimisation and } \\
\text { competitive factor markets, also use of "Fisher } \\
\text { and Hulten index of total factor productivity } \\
\text { procedure }\end{array}$ & $\begin{array}{l}\text { Mesonada Carlos S. J (1998) } \\
\text { Fernandeza; M. C. A. Herruzoa C.; } \\
\text { Evenson R. E. Rudolf B. and } \\
\text { Zurlinden M.(2010), Parrotta et al } \\
\text { (2010) }\end{array}$ \\
\hline 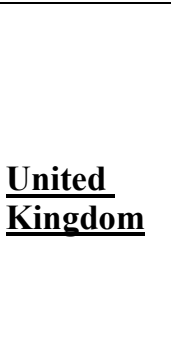 & $\begin{array}{l}\text { Input to output ratio } \\
\text { and multi factor } \\
\text { model as Total } \\
\text { Factor Value } \\
\text { Productivity }\end{array}$ & $\begin{array}{l}\text { Standard productivity analysis normally starts by } \\
\text { assuming a production function; a map-ping } \\
\text { from input quantities to output quantities with } \\
\text { this assumption:" perfect competition in product } \\
\text { markets" .also Using a factor model, construct a } \\
\text { minimum-variance index based on patent } \\
\text { characteristics and using multiple indicators } \\
\text { substantially reduces the Measured variance in } \\
\text { quality }\end{array}$ & $\begin{array}{l}\text { Lanjouw J. and Schankermann .M } \\
\text { (2002), Atkinson } \\
\text { (2005),RalfMartin(2008) Peñaloza } \\
\text { et al. (2010) }\end{array}$ \\
\hline$\frac{\text { United }}{\text { stated }}$ & $\begin{array}{l}\text { Ratio approaches, } \\
\text { Few indexes and } \\
\text { DEA analyses }\end{array}$ & $\begin{array}{l}\text { Using of multifactor and some indexes to } \\
\text { compute industry productivity and Also he } \\
\text { compared changes in output to changes in a } \\
\text { composite of all the inputs used in production }\end{array}$ & $\begin{array}{c}\text { Dean and Harper(1998), } \\
\text { Gullickson (1995), Jack Triplett } \\
\text { and Barry Bosworth(2007) and } \\
\text { Harper, Bhavani K .R ,Kinoshita, } \\
\text { and S.Rosenthal (2010) }\end{array}$ \\
\hline
\end{tabular}

Note: In this table important researches and studies in Canada, Germany. India, Iran, Japan, South Korea, Taiwan, Spain , United Kingdom and United stated are reviewed to recognize Productivity Measurement Base in these countries.

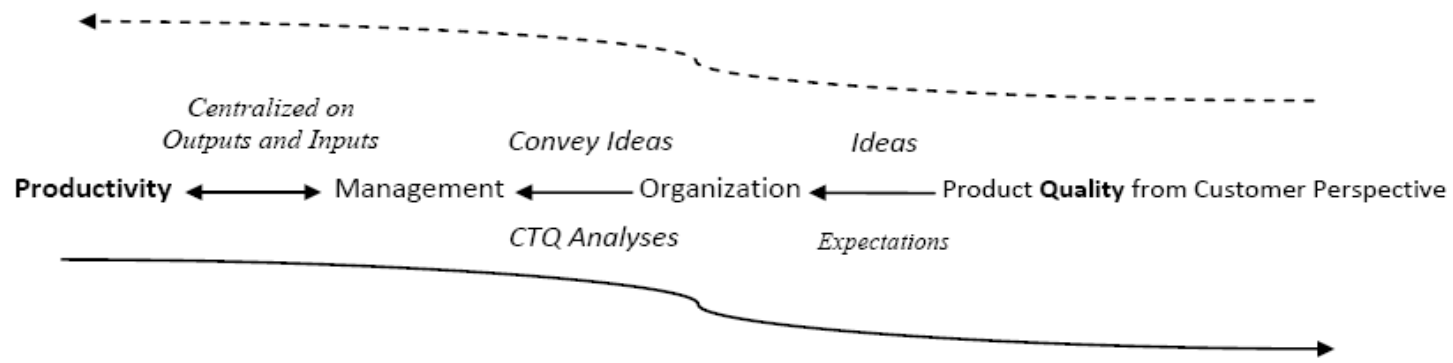

Figure 1. Relation between Productivity and Quality

Note: We can employ customer voice and CTQ analysis in order to extract Customers expatiations, requests and ideas. Organization will review these opinions and ideas then convey them to operational managers for appropriate feedback and provide customer's needs. One of the main factors which should be considered is quality 